\title{
Matrine from Vietnamese sophora root inhibits the growth of oral squamous cell carcinoma cells in vitro and in vivo
}

\author{
Yongwei LI ${ }^{1 * \#}$, Haishu LIN"1*, Ni DENG ${ }^{1}$, Lili XIE¹, Renhui LUO²
}

\begin{abstract}
This study investigated the extraction of matrine from Vietnamese sophora root and its in vitro and in vivo inhibitory effects on oral squamous cell carcinoma (OSCC) cells. Matrine was extracted from Vietnamese sophora root using microwave-assisted extraction technology and purified using macroporous adsorption resin. Human OSCC Tca8113 cells were treated with matrine with concentration of $0,0.5,1,2,4$ and $8 \mathrm{~g} / \mathrm{L}$. The proliferation and apoptosis of cells were detected. OSCC cells were transplanted in the nude mice, and then the nude mice were treated with normal saline, cyclophosphamide (CTX) $\left(20 \mathrm{mg} \cdot \mathrm{kg}^{-1}\right)$ and matrine $\left(100 \mathrm{mg} \cdot \mathrm{kg}^{-1}\right)$, respectively. The optimized extraction parameters of matrine were obtained. The in vitro experiments showed that, matrine inhibit the proliferation of Tca8113 cells and induced the cell apoptosis. The in vivo experiments found that, the tumor inhibition rate of matrine was basically equivalent to that of CTX. In addition, compared with CTX, matrine had no obvious toxic side effect on the liver and kidney function of nude mice. These results indicate that, matrine has obvious in vitro and in vivo inhibitory effects on OSCC cells, with no obvious toxic side effect on the liver and kidney function.
\end{abstract}

Keywords: extraction; matrine; oral squamous cell carcinoma.

Practical Application: Matrine can be extracted from Vietnamese sophora root, and may be used to treat oral squamous cell carcinoma.

\section{Introduction}

Matrine is the main active ingredient of Vietnamese sophora root, a medicinal plant. Recent studies have indicated that, matrine has antitumor, antiviral, anti-inflammatory, anti-arrhythmia, immunity enhancement and liver protection activities (Zhaowu et al., 2009; Yang et al., 2012; Liu et al., 2014). In addition, it can reduce the side effects of chemotherapy, and improve patient's tolerance to treatment (Rong et al., 2015). The anti-tumor effect of matrine has gradually become the focus of research. Matrine is expected to be a new and promising antitumor drug. For the time being, the researches on antitumor effects of matrine are mainly focused on the liver cancer (Ou et al., 2014), lung cancer (Zhang et al., 2009b), prostate cancer (Zhang et al., 2012a), leukemia cells (Zhang et al., 2012b) and others. Oral squamous cell carcinoma (OSCC) is a common malignant tumor of the head and neck. It is highly malignant, aggressive and prone to lymph node metastasis (Ren et al., 2016). At present, the treatment of OSCC is often dominated by comprehensive treatment of surgery and radiotherapy. The surgical treatment will bring great trauma to the body, and cause a series of complications. The radiotherapy will simultaneously damage the normal tissue or organ when killing tumor cells. In addition, the tumor has certain resistance to radiation ( $\mathrm{Li}$ et al., 2017). This greatly hinders the improvement of the cure rate of OSCC. Until now the inhibitory effect of matrine on OSCC are less reported. It is hypothesized that matrine has the inhibitory effects on OSCC cells. This study investigated the extraction of matrine from Vietnamese sophora root and its in vitro and in vivo inhibitory effects on OSCC Tca811 cells. The objective was to provide a basis for preparation of matrine and its clinical application to treatment of OSCC.

\section{Materials and methods}

\subsection{Extraction of matrine from Vietnamese sophora root}

One hundred gram of Vietnamese sophora root raw material (Shanghai Kanglang Biotechnology Co., Ltd., Shanghai, China) was placed in the multi-functional grinder. After grinding and passing $250 \mu \mathrm{m}$ sieves, the powder was obtained. The matrine was extracted using microwave-assisted extraction technology. One hundred gram of Vietnamese sophora root powder was placed in the extraction tank of WF-4000C microwave extraction system (Shanghai EU Microwave Chemistry Technology Co. Ltd., Shanghai, China), followed by addition of ethanol-water solvent. The microwave assisted extraction process was started under conditions including certain ethanol concentration, ratio of liquid to solid, microwave power, extraction time, and extraction temperature. After extraction, the liquid was filtered and concentrated. Water was added to dissolve the residue. The solution was added to the macroporous adsorption resin (type SP825; Zhengzhou Qinshi Technology Co., Ltd., Zhengzhou, China). After elution using appropriate solvent, the matrine product was obtained. The extraction parameters were optimized through single-factor experiment and Box-Behnken design, using matrine product yield and content as examined indexes.

Received 03 Apr., 2018

Accepted 07 Aug., 2018

${ }^{1}$ Department of Stomatology, Hainan General Hospital, Haikou, China

${ }^{2}$ Department of Stomatology, Guangzhou Hospital of Integrated Traditional and Western Medicine, Guangzhou, China

*Corresponding author: yongweili1@sina.com

${ }^{\#}$ Contributed equally 


\subsection{Cell culture}

Tca8113 cells (Nanjing KeyGen Biotech. Co., Ltd., Nanjing, China) were cultured in RPMI 1640 culture medium containing $10 \% \mathrm{FBS}, 100 \mathrm{U} / \mathrm{mL}$ penicillin and $100 \mathrm{U} / \mathrm{mL}$ streptomycin ( $\mathrm{pH}=7.2$ ) (Sigma-Aldrich Corp., MO, USA) in electric constant temperature incubator $\left(37^{\circ} \mathrm{C}, 5 \% \mathrm{CO}_{2}\right)$. The culture medium was exchanged once every two days. The cells in logarithmic growth phase were collected for further experiments.

\subsection{Determination of Tca8113 cell proliferation}

MTT method was use to determine the proliferation of Tca 8113 cells. Tca 8113 cells $\left(2 \times 10^{6}\right.$ cell $\left./ \mathrm{mL}\right)$ were incubated in 96-well culture plate, $50 \mu \mathrm{L}$ per well. After the cell adherence appeared, the original culture medium was removed. The cells were divided into 6 groups, 6 wells in each group. Matrine was added to the well, and the culture medium was added to make the final volume $100 \mu \mathrm{L}$. In these 6 groups, the final matrine concentration was $0,0.5,1,2,4$ and $8 \mathrm{~g} / \mathrm{L}$, respectively. After culture $\left(37^{\circ} \mathrm{C}, 5 \% \mathrm{CO}_{2}\right)$ for 24,48 and $72 \mathrm{~h}$, the culture medium was sucked, and $20 \mu \mathrm{L}$ MTT (Sigma-Aldrich Corp., MO, USA) was added to each well, followed by culture for $6 \mathrm{~h}$. The supernatant was discarded. Fifty microlitre of DMSO (Sigma-Aldrich Corp., MO, USA) was added to each well, followed by oscillation for $10 \mathrm{~min}$. The optical density (OD) of cell solution was detected using microplate reader at the wavelength of $630 \mathrm{~nm}$. The inhibition rate on cell proliferation was calculated as follows: inhibition rate $=\left(\mathrm{OD}_{\text {control group }}-\mathrm{OD}_{\text {experimental group }}\right) / \mathrm{OD}_{\text {control group }} \times 100 \%$.

\subsection{Determination of Tca8113 cell apoptosis}

Flow cytometry analysis was performed to determine the apoptosis of Tca8113 cells. After treatment with different concentration of matrine for $48 \mathrm{~h}$, the culture medium was sucked off, followed by centrifugation at $256 \mathrm{X} \mathrm{g}$ for $5 \mathrm{~min}$. The cells were washed with PBS for 3 times. Then, $1 \mathrm{~mL}$ of propidium iodide and $1 \mathrm{~mL}$ of RNA enzyme without DNA enzyme contamination (Fuzhou Maixin Biotechnology Development Co., Ltd., Fuzhou, China) were added, with final of concentration of $50 \mu \mathrm{g} / \mathrm{mL}$. After dyeing for $0.5-1 \mathrm{~h}$, the cell apoptosis and cell cycle were measured using flow cytometer, and the percentage of cells in different phases and the apoptosis rate were calculated.

\subsection{Establishment of Tca8113 transplanted tumor model in nude mice and treatment with matrine}

Tca8113 cells in logarithmic growth phase were collected, and the single cell suspension $\left(1 \times 10^{7}\right.$ cells $\left./ \mathrm{mL}\right)$ was prepared. $0.2 \mathrm{~mL}$ of cell suspension was subcutaneously inoculated at the right dorsal side of BALB/c nude mice (male, 30-45 days old, 18-22 g; Shanghai Silaike Experimental Animal Co., Ltd, Shanghai, China). When the diameter of tumor reached $5 \mathrm{~mm}$, the nude mice were randomly divided into model, cyclophosphamide (CTX) and matrine group, with 12 rats in each group. The matrine group was intragastrically administrated with matrine with dose of $100 \mathrm{mg} \cdot \mathrm{kg}^{-1} \cdot \mathrm{day}^{-1}$. The CTX group was intragastrically administrated with CTX (20 mg. $\mathrm{kg}^{-1} \cdot \mathrm{day}^{-1}$, Shanxi Qian Yuan
Pharmaceutical Co., Ltd., Datong, China). The model group was given with the same volume of normal saline. The treatment was continued for 20 days.

\subsection{Detection of blood routine and liver and kidney functions in nude mice}

On the second day after treatment, the orbital blood of mice was taken. The liver and kidney function indexes including alanine aminotransferase (ALT), aspartate aminotransferase (AST) creatinine (CREA) and urea were detected using ES-200 full automatic blood analyzer (E-LAB Biological Science \& Technology Co., Ltd., Nanjing, China).

\subsection{Determination of Tca8113 transplanted tumor growth in nude mice}

After taking the orbital blood, the mice were sacrificed, and the complete tumor tissue was taken. The fiber film of the tumor was removed, and then the tumor tissue was weighted on the electronic balance. The tumor inhibition rate was calculate as follows: tumor inhibition rate $(\%)=$ (average tumor mass in model group - average tumor mass in experiment group) / average tumor mass in model group) $\times 100 \%$.

\subsection{Statistical analysis}

All statistical analysis was carried out using SPSS20.0 software. Each experiment was repeated for three times, and the data were presented as mean \pm standard deviation. The comparison among different groups was performed using one way single-factor analysis with Dunnet's post hoc test. $\mathrm{P}<0.05$ was considered as statistically significant.

\section{Results}

\subsection{Optimized extraction parameters and extraction results}

After single factor-experiments and optimization based on Box-Behnken design, the optimized microwave-assisted matrine extraction parameters from Vietnamese sophora root were as follows: ethanol concentration, $70 \%$; ratio of liquid to solid, 20: 1 (mL: g); microwave power, $500 \mathrm{~W}$; extraction time, $20 \mathrm{~min}$; extraction temperature, $75^{\circ} \mathrm{C}$. With these parameters, the extraction yield of matrine product was $1.21 \%$. After purification using macroporous adsorption resin, the content of matrine in final product was $73.62 \%$.

\subsection{Effects of matrine on proliferation of Tca8113 cells}

Matrine with all concentrations had the inhibitory effect on proliferation of Tca8113 cells. The inhibitory effect was increased with treatment time prolonging and concentration increasing. There was significant difference of inhibitory rate between each two concentrations from 0.5 to $4 \mathrm{~g} / \mathrm{L}$ at the same treatment time point $(\mathrm{P}<0.05)$, with no significant difference between $4 \mathrm{~g} / \mathrm{L}$ and $8 \mathrm{~g} / \mathrm{L}$ matrine groups $(\mathrm{P}>0.05)$. There was significant difference of inhibitory rate between each two treatment time points with the same concentration $(\mathrm{P}<0.05)$ (Figure 1$)$. 


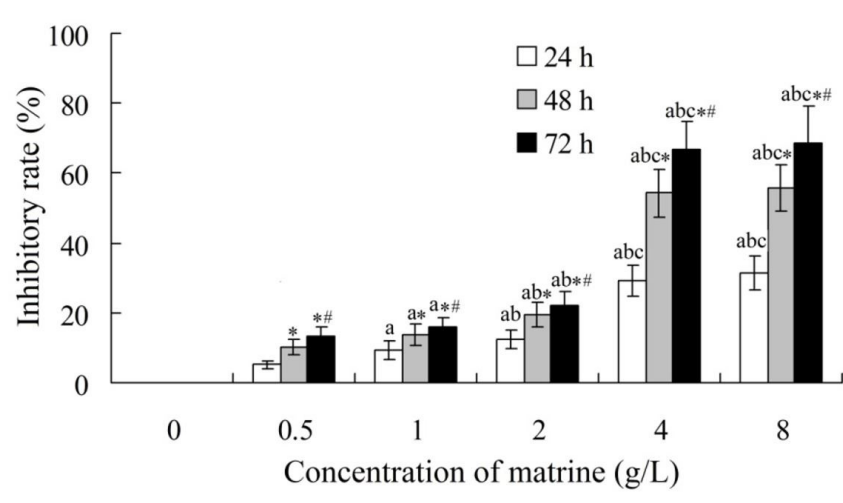

Figure 1. Effects of matrine on proliferation of Tca8113 cells. ${ }^{\text {a }}<0.05$ compared with $0.5 \mathrm{~g} / \mathrm{L}$ matrine; ${ }^{\mathrm{b}} \mathrm{P}<0.05$ compared with $1 \mathrm{~g} / \mathrm{L}$ matrine; ${ }^{\mathrm{c}} \mathrm{P}<0.05$ compared with $2 \mathrm{~g} / \mathrm{L}$ matrine; ${ }^{\star} \mathrm{P}<0.05$ compared with $24 \mathrm{~h}$ time point; ${ }^{~} \mathrm{P}<0.05$ compared with $48 \mathrm{~h}$ time point.

Table 1. Effects of matrine on apoptosis of Tca8113 cells.

\begin{tabular}{cccc}
\hline \multirow{2}{*}{ Concentration $(\mathrm{g} / \mathrm{L})$} & \multicolumn{3}{c}{ Apoptosis rate $(\%)$} \\
\cline { 2 - 4 } & $24 \mathrm{~h}$ & $48 \mathrm{~h}$ & $72 \mathrm{~h}$ \\
\hline 0 & $0.6 \pm 0.1$ & $2.0 \pm 0.5^{\star}$ & $4.2 \pm 0.8$ \\
0.5 & $1.7 \pm 0.4^{\mathrm{a}}$ & $3.1 \pm 4.7^{\mathrm{a} \star}$ & $5.2 \pm 1.7^{\mathrm{a} * \#}$ \\
1 & $2.8 \pm 0.5^{\mathrm{ab}}$ & $5.3 \pm 1.3^{\mathrm{ab} *}$ & $11.8 \pm 2.1^{\mathrm{ab} \star *}$ \\
2 & $3.4 \pm 0.5^{\mathrm{abc}}$ & $32.9 \pm 4.3^{\mathrm{abc} *}$ & $49.4 \pm 6.9^{\mathrm{abc} * \#}$ \\
4 & $22.6 \pm 2.4^{\mathrm{abcd}}$ & $62.2 \pm 7.2^{\mathrm{abcd} *}$ & $73.1 \pm 8.2^{\mathrm{abcd} * *}$ \\
8 & $24.1 \pm 3.6^{\mathrm{abcd}}$ & $65.3 \pm 8.9^{\mathrm{abcd} *}$ & $72.2 \pm 9.4^{\mathrm{abcd} * *}$ \\
\hline
\end{tabular}

${ }^{a} \mathrm{P}<0.05$ compared with $0 \mathrm{~g} / \mathrm{L}$ matrine; ${ }^{\mathrm{b}} \mathrm{P}<0.05$ compared with $0.5 \mathrm{~g} / \mathrm{L}$ matrine; ${ }^{\mathrm{c}} \mathrm{P}<0.05$ compared with $1 \mathrm{~g} / \mathrm{L}$ matrine; ${ }^{\mathrm{d}} \mathrm{P}<0.05$ compared with $2 \mathrm{~g} / \mathrm{L}$ matrine; ${ }^{*} \mathrm{P}<0.05$ compared with $24 \mathrm{~h}$ time point; ${ }^{*} \mathrm{P}<0.05$ compared with $48 \mathrm{~h}$ time point.

\subsection{Effects of matrine on apoptosis of Tca8113 cells}

Table 1 showed that, matrine with all concentrations could promote the apoptosis of Tca8113 cells. The apoptosis rate was increased with treatment time prolonging and concentration increasing, respectively. There was significant difference of apoptosis rate between each two concentrations from 0 to $4 \mathrm{~g} / \mathrm{L}$ at the same treatment time point $(\mathrm{P}<0.05)$, with no significant difference between $4 \mathrm{~g} / \mathrm{L}$ and $8 \mathrm{~g} / \mathrm{L}$ matrine groups $(\mathrm{P}>0.05)$. There was significant difference between each two treatment time points with the same matrine concentration $(\mathrm{P}<0.05)$.

\subsection{Effects of matrine on growth of Tca8113 transplanted tumor in nude mice}

Table 2 showed that, the tumor masses in model, CTX and matrine groups were $0.9 \pm 0.1,0.4 \pm 0.1$ and $0.5 \pm 0.1$, respectively, and the inhibition rates of tumor in CTX and matrine groups were $55.5 \pm 6.4 \%$ and $44.5 \pm 5.8 \%$, respectively. The tumor mass in CTX and matrine groups was significantly higher than that model group, respectively $(\mathrm{P}<0.05)$. There was no significant difference of tumor mass or tumor inhibition rate between CTX and matrine groups $(\mathrm{P}>0.05)$.
Table 2. Effects of matrine on growth of Tca8113 transplanted tumor in nude mice.

\begin{tabular}{cccc}
\hline Group & $\mathrm{n}$ & Tumor mass $(\mathrm{g})$ & Inhibition rate (\%) \\
\hline Model & 12 & $0.9 \pm 0.1$ & - \\
CTX & 12 & $0.4 \pm 0.1^{\mathrm{a}}$ & $55.5 \pm 6.4$ \\
Matrine & 12 & $0.5 \pm 0.1^{\mathrm{a}}$ & $44.5 \pm 5.8$ \\
\hline${ }^{\mathrm{a} P}<0.05$ compared with model group; CTX $=$ cyclophosphamide.
\end{tabular}

Table 3. Effects of matrine on liver and kidney functions of nude mice.

\begin{tabular}{cccccc}
\hline Group & $\mathrm{n}$ & $\begin{array}{c}\text { ALT } \\
(\mu \mathrm{U} / \mathrm{mL})\end{array}$ & $\begin{array}{c}\text { AST } \\
(\mu \mathrm{U} / \mathrm{mL})\end{array}$ & $\begin{array}{c}\text { CREA } \\
(\mathrm{nmol} / \mathrm{mL})\end{array}$ & $\begin{array}{c}\text { Urea } \\
(\mu \mathrm{mol} / \mathrm{mL})\end{array}$ \\
\hline Model & 12 & $54 \pm 8$ & $452 \pm 63$ & $7 \pm 2$ & $4 \pm 1$ \\
CTX & 12 & $79 \pm 10^{\mathrm{a}}$ & $590 \pm 72^{\mathrm{a}}$ & $9 \pm 3$ & $6 \pm 2$ \\
Matrine & 12 & $56 \pm 5^{\mathrm{b}}$ & $472 \pm 97^{\mathrm{b}}$ & $6 \pm 3$ & $4 \pm 1$ \\
\hline${ }^{\mathrm{a}} \mathrm{P}<0.05$ compared with model group; ${ }^{\mathrm{b}}<0.05$ compared with CTX group; \\
ALT = alanine aminotransferase; AST = aspartate aminotransferase; CREA = creatinine; \\
CTX = cyclophosphamide.
\end{tabular}

\subsection{Effects of matrine on liver and kidney functions of nude mice}

The ALT and AST levels in CTX group were significantly higher than those in model group, respectively $(\mathrm{P}<0.05)$, and those in matrine group were significantly lower than those in CTX group, respectively $(\mathrm{P}<0.05)$. There was no significant difference of CREA or urea level among 3 groups $(P>0.05)$ (Table 3).

\section{Discussion}

Matrine-type alkaloids are the often existing natural products. They are represented by matrine, and included oxymatrine, Sophora fruit alkali, sophoridine, sophoranol and alkali and $\mathrm{N}$-oxysophocarpine. Their structures belong to the quinazolines, and the molecular skeleton can be regarded as the impurity of the two quinazoline and pyridine rings (Pan et al., 2015). A number of pharmacological studies and clinical practice have shown that, matrine can be used in the treatment of hepatitis (Ma et al., 2013), liver fibrosis (Yu et al., 2014), arrhythmia (Xin \& Liu, 2011) and ischemia (Zhang et al., 2011). At the same time, matrine has clear functions in calming, relieving pain, regulating body temperature, enhancing myocardial function, treating hypertension and even resisting virus (Zhou et al., 2008). In addition, matrine plays an important role in anti-tumor, immune regulation and other aspects of treatment (Liu et al., 2014).

In recent years, through continuous in vitro and clinical experiments, the anti-tumor functions of matrine have obtained more and more attention in scientific research field. The anti-tumor mechanism of matrine can be summarized as follows: i) matrine can induce the differentiation of tumor cells and inhibit the proliferation of tumor cells in acertain extent; ii) matrine can promote the further apoptosis of tumor cells; iii) matrine can resist the adhesion of tumor cells, and prevent the tumor cell invasion and metastasis; iv) matrine can reverse the drug resistance of tumor cells, and reduce the side effects of chemotherapy drugs, thus improving the life quality of patients 
and prolonging the survival time; v) matrine has the preventive chemotherapy effect (Liu et al., 2014). The effects of matrine on induced differentiation proliferation and apoptosis of tumor cells have been the focus of research.

It is found that, matrine can inhibit the growth of a variety of cancer cells, such as gastric cancer cells, liver cancer cells, breast cancer, bile duct cancer cells, colon cancer cells and renal cell carcinoma cells, with a dose-dependent and time-dependent manner. In addition, matrine can induce the apoptosis of above tumor cells (Zhou et al., 2008). The reason may be that, matrine is involved in the expression of tumor associated genes, thus causing the cell apoptosis. Zhang et al. (2009a) have found that, matrine can induce the autophagy of rat $\mathrm{C} 6$ glioma cells. In this study, the in vitro experiments were performed to investigate the inhibitory effects of matrine on OSCC Tca8113 cells. Results showed that, matrine with all concentrations inhibit the proliferation of Tca8113 cells, and induced the cell apoptosis. These effects basically had the dose-dependent and time-dependent manner. The difference of effect between $4 \mathrm{~g} / \mathrm{L}$ and $8 \mathrm{~g} / \mathrm{L}$ matrine groups was not significant $(\mathrm{P}>0.05)$. This indicates that, $4 \mathrm{~g} / \mathrm{L}$ may the appropriate concentration of matrine in inhibiting the proliferation of Tca8113 cells, and inducing the cell apoptosis.

The in vivo experiments showed that, the tumor mass in CTX and matrine groups was significantly higher than that model group, respectively $(\mathrm{P}<0.05)$. There was no significant difference between of tumor mass or tumor inhibition rate between CTX and matrine groups $(\mathrm{P}>0.05)$. In addition, compared with CTX group, the ALT and AST levels in matrine group were significantly decreased $(\mathrm{P}<0.05)$. This indicates that, matrine has no obvious toxic side effect on the liver and kidney function of nude mice with Tca8113 transplanted tumor.

\section{Conclusion}

The present study has obtained the optimized parameters in microwave-assisted extraction of matrine from Vietnamese sophora root. The content of matrine in final product was $73.62 \%$. Matrine has the in vitro and in vivo inhibitory effects on the growth of human OSCC Tca8113 cells. It has no obvious toxic side effect on the liver and kidney function of nude mice. This study has provided a basis for preparation of matrine and the clinical application of matrine to treatment of OSCC. In this study, we have not investigated the molecular mechanism about the inhibitory effects of matrine on OSCC Tca 8113 cells. This may be a limitation of this study, and should be resolved in next studies.

\section{References}

Li, B., Gao, Y. J., Wu, X. Y., Cui, J., Long, Y., Xu, J. L., \& Ding, D. G. (2017). Tumor-initiating cells contribute to radiation resistance in primary human renal clear cell carcinomas by activating the DNA damage checkpoint response. Oncology Letters, 14(3), 3261-3267. http://dx.doi. org/10.3892/ol.2017.6504. PMid:28927075.

Liu, Y., Xu, Y., Ji, W., Li, X., Sun, B., Gao, Q., \& Su, C. (2014). Anti-tumor activities of matrine and oxymatrine: literature review. Tumour Biology, 35(6), 5111-5119. http://dx.doi.org/10.1007/s13277-014-1680-z. PMid:24526416.

Ma, Z. J., Li, Q., Wang, J. B., Zhao, Y. L., Zhong, Y. W., Bai, Y. F., Wang, R. L., Li, J. Y., Yang, H. Y., Zeng, L. N., Pu, S. B., Liu, F. F., Xiao, D. K., Xia,
X. H., \& Xiao, X. H. (2013). Combining oxymatrine or matrine with lamivudine increased its antireplication effect against the Hepatitis B virus in vitro. Evidence-Based Complementary and Alternative Medicine, 2013(1), 186573. PMid:23401707.

Ou, X., Chen, Y., Cheng, X., Zhang, X., \& He, Q. (2014). Potentiation of resveratrol-induced apoptosis by matrine in human hepatoma HepG2 cells. Oncology Reports, 32(6), 2803-2809. http://dx.doi.org/10.3892/ or.2014.3512. PMid:25269486.

Pan, Q. M., Li, Y. H., Hua, J., Huang, F. P., Wang, H. S., \& Liang, D. (2015). Antiviral matrine-type alkaloids from the Rhizomes of Sophora tonkinensis. Journal of Natural Products, 78(7), 1683-1688. http://dx.doi. org/10.1021/acs.jnatprod.5b00325. PMid:26132528.

Ren, Z. H., Zhang, C. P., \& Ji, T. (2016). Expression of SOX2 in oral squamous cell carcinoma and the association with lymph node metastasis. Oncology Letters, 11(3), 1973-1979. http://dx.doi.org/10.3892/ol.2016.4207. PMid:26998109.

Rong, B., Zhao, C., Gao, W., \& Yang, S. (2015). Matrine promotes the efficacy and safety of platinum-based doublet chemotherapy for advanced nonsmall cell lung cancer. International Journal of Clinical and Experimental Medicine, 8(9), 14701-14717. PMid:26628952.

Xin, H. B., \& Liu, S. F. (2011). Effects of matrine on myocardial contraction and arrhythmia in isolated heart atria. Chinese Journal of Basic Medicine in Traditional Chinese Medicine, 17(6), 633-632.

Yang, Y., Xiu, J., Zhang, X., Zhang, L., Yan, K., Qin, C., \& Liu, J. (2012). Antiviral effect of matrine against human enterovirus 71. Molecules, 17(9), 10370-10376. http://dx.doi.org/10.3390/molecules170910370. PMid:22932217.

Yu, J. L., Li, J. H., Chengz, R. G., Ma, Y. M., Wang, X. J., \& Liu, J. C. (2014). Effect of matrine on transforming growth factor $\beta 1$ and hepatocyte growth factor in rat liver fibrosis model. Asian Pacific Journal of Tropical Medicine, 7(5), 390-393. http://dx.doi.org/10.1016/S1995-7645(14)600626. PMid:25063067.

Zhang, F., Wang, X., Tong, L., Qiao, H., Li, X., You, L., Jiang, H., \& Sun, X. (2011). Matrine attenuates endotoxin-induced acute liver injury after hepatic ischemia/reperfusion in rats. Surgery Today, 41(8), 1075-1084. http://dx.doi.org/10.1007/s00595-010-4423-9. PMid:21773896.

Zhang, P., Wang, Z., Chong, T., \& Ji, Z. (2012a). Matrine inhibits proliferation and induces apoptosis of the androgen-independent prostate cancer cell line PC-3. Molecular Medicine Reports, 5(3), 783-787. PMid:22159447.

Zhang, S., Qi, J., Sun, L., Cheng, B., Pan, S., Zhou, M., \& Sun, X. (2009a). Matrine induces programmed cell death and regulates expression of relevant genes based on PCR array analysis in C6 glioma cells. Molecular Biology Reports, 36(4), 791-799. http://dx.doi.org/10.1007/s11033-0089247-y. PMid:18392946.

Zhang, S., Zhang, Y., Zhuang, Y., Wang, J., Ye, J., Zhang, S., Wu, J., Yu, K., \& Han, Y. (2012b). Matrine induces apoptosis in human acute myeloid leukemia cells via the mitochondrial pathway and Akt inactivation. PLoS One, 7(10), e46853. http://dx.doi.org/10.1371/journal.pone.0046853. PMid:23056487.

Zhang, Y., Zhang, H., Yu, P., Liu, Q., Liu, K., Duan, H., Luan, G., Yagasaki, K., \& Zhang, G. (2009b). Effects of matrine against the growth of human lung cancer and hepatoma cells as well as lung cancer cell migration. Cytotechnology, 59(3), 191-200. http://dx.doi.org/10.1007/s10616-0099211-2. PMid:19649719.

Zhaowu, Z., Xiaoli, W., Yangde, Z., \& Nianfeng, L. (2009). Preparation of matrine ethosome, its percutaneous permeation in vitro and antiinflammatory activity in vivo in rats. Journal of Liposome Research, 19(2), 155-162. http://dx.doi.org/10.1080/08982100902722381. PMid:19241204.

Zhou, J., Mei, Y., \& Li, Y. I. (2008). (2008). A review on pharmacological action of matrine-type alkaloids. Journal of Pediatric Pharmacy, 14(1), 61-64. 